John Komlos

\title{
Has Creative Destruction become more
} Destructive?

\author{
${ }^{1}$ Department of Economics, University of Munich, Ludwigstr. 33-IV, Munich 80539, Germany, E-mail: john.komlos@econ- \\ hist.vwl.uni-muenchen.de
}

\begin{abstract}
:
Schumpeter's concept of creative destruction as the engine of capitalist development is well-known. However, that the destructive part of creative destruction is a social and economic cost and therefore biases our estimate of the impact of the innovation on GDP is hardly acknowledged, with the notable exception of Witt (1996. "Innovations, Externalities and the Problem of Economic Progress." Public Choice 89:113-30). Admittedly, during the First and Second Industrial Revolutions the magnitude of the destructive component of innovation was no doubt small compared to the net value added to GDP. However, we conjecture that recently the destructive component of innovations has increased relative to the size of the creative component as the new technologies are often creating products which are close substitutes for the ones they replace whose value depreciates substantially in the process of destruction. Consequently, the contribution of recent innovations to GDP is likely upwardly biased. This note calls for further research in innovation economics in order to measure and decompose the effects of innovations into their creative and destructive components in order to provide improved estimates of their contribution to GDP and to employment.
\end{abstract}

Keywords: creative destruction, Schumpeter, innovation

JEL classification: B52, O3

DOI: 10.1515/bejeap-2016-0179

\section{Introduction}

Economic growth is fueled to a considerable extent - some would say primarily-by the innovations of largerthan-life entrepreneurs, a process Joseph Schumpeter famously dubbed "creative destruction" (Aghion \& Howitt, 1998; Schumpeter, 1942 ). In his dynamic conceptual framework entrepreneurs invented new products or new ways of doing things in order to increase efficiency, improve quality, or lower price, thereby bringing about the obsolescence of competing firms whose management lagged behind and failed to seize those opportunities. ${ }^{1}$ The ancient is destroyed in the process of creating the new in a Darwinian - or perhaps even more appropriately - in a Spencerian competitive process of survival of the fittest entrepreneur - or the most profitable firm (Hodgson 2002 ). Thus, creativity is at once constructive and creative but also destructive: evolutionary progress is by no means painless and has never been (Akerlof \& Shiller, 2015; Schubert, 2015; Tanner, 1996 ). In other words, there are not only gainers but also losers and society pays for the new with various levels of "hardship" and even "a lot of suffering" (Krugman, 2014; Witt, 1996 ).

This note has the modest aim of suggesting that the destructive component of innovations has increased recently relative to the income-enhancing creative part and thereby inspire other researchers to undertake the more painstaking task of estimating the trend in these variables over time. This brainstorming essay is an appeal for research (especially at the firm or sectoral level) on this issue; a systemic testing of this conjecture is outside of its scope.

\section{Schumpeter's Creativity Ratio}

Schumpeter, and most who followed in his footsteps, asserted quite confidently that creative destruction was, in the main, income enhancing at least in the long run (Witt 1996 ). In order to explore this aspect of his concept we decompose an innovation into a creative (C) and a destructive component (D) measured either in monetary units or in employment. In order to assess the effect of an innovation on GDP or employment, we define Schumpeter's creativity ratio as $\mathrm{ScR}=C-\frac{D}{C}$. $D$ can be viewed as a negative externality - a cost that is imposed on third 
parties without their consent (Witt 1996 ). While $C$ is the measured value added to GDP by the innovation, $C-D$ is its actual contribution (net of the negative externality). The primary purpose of this essay is to urge empirical investigations in order to estimate the trend in ScR and thereby to test systematically the proposition that it has been declining recently. ${ }^{2}$

Note first that the negative externality can impact GDP or employment and it can fall on both producers and on consumers. As an example of an externality that effects the former consider an innovation by firm A that creates a new product at time $t=1$ that forces the closing of another firm, B. Suppose that A's output at time $t=1$ is valued at $C=\$ 10$ and that at $t=0$ (i. e., prior to the innovation) firm $\mathrm{B}^{\prime} \mathrm{s}$ output was $D=\$ 4$; which suddenly becomes obsolete so that its value declines to zero. The depreciation of that part of B's capital equipment that cannot be put to other uses, as well as its employees who are unable to find work elsewhere, is a negative externality valued at, $\$ 4$ a year; its prior value added to GDP.

For instance, I might include the value of newspapers (net of raw materials such as paper and ink) produced by a printing press that ends up in the scrap pile while its 50-year-old operator becomes permanently unemployed on account of innovations by firm A in the IT sector. The company producing newspapers had depreciated fully the printing press long ago so that it is carried on the books at zero effective value although it was still producing newspapers until then. Along came the internet, the demand for the newspapers decreased, the company ceased operation, and the printing press became scrap. Such destruction of physical capital would not be included in the calculations of the U.S. Bureau of Economic Analysis, because the book value of the printing press was zero at the time of bankruptcy. ${ }^{3}$ At $t=1$ the printing press and its operator are no longer contributing to economic activity but they would have been contributing in the absence of the innovation. Thus, the contribution of the innovation is not a net value added to GDP. It appears as though firm A contributes $\$ 10$ but its actual contribution (net of that which would have obtained in its absence) is $\$ 6$. Thus, $C$, the measured value of the new product is not a net value added to GDP, because of the negative externality produced. In this example, the innovation created a net gain in GDP of $(C-D)=\$ 6$ with $\mathrm{ScR}=\frac{10-4}{10}=0.6$. Disregarding this difference between gross and net contribution of the innovation to GDP is misleading, because the appearance is as though the innovation is more important than it actually is. Although the growth in GDP in this case is correctly measured as $\$ 6$ (the difference in $\mathrm{A}^{\prime}$ s output at $t=1$ and that of $\mathrm{B}^{\prime} \mathrm{s}$ at $t=0$ ), the appearance is that $\mathrm{A}^{\prime} \mathrm{s}$ contribution is $\$ 10$.

Another kind of externality falls on consumers. In this version of creative destruction the firm introduces a new product that does not bankrupt another firm but renders unexpectedly obsolete a consumption good produced either by itself or another firm. The obsolescence can be planned or not. Planned obsolescence is a favorite strategy of oligopolies for products such as video games, textbooks, software, consumer electronics, where upgrades and the latest versions with minor improvements are introduced periodically with the aim of convincing the consumer of its superiority in spite of minor improvements. Such a strategy depreciates the value of the prior version and increases the profits of the corporation. ${ }^{4}$ Thus, new versions of existing products frequently do not add much net value in proportion to the amount by which they increase GDP.

Yet, this strategy can be profitable because the quality of the new product may not be immediately obvious and because firms can manipulate consumers by bombarding them with advertisements which instill in them the feeling that they need the newest version of a particular product, although the older one is still functioning well (Akerlof and Shiller 2015 ). ${ }^{5}$ Madison Avenue's advertisement barrage works in many ways to exploit the psychological weaknesses of human nature in order to coax and tempt consumers into craving its products. ${ }^{6}$ Furthermore, they use celebrities to appeal to our instinct to conform that accompanies the "craving for acceptance" and sexual innuendos are often not far away (Fromm $1955,149-151)$. These advertisements define the terms on which an individual can become a respected member of the society. Madison Avenue also devises gimmicks as Pavlovian conditioning starting with children in order to create a market for their products.

New products can win customers also by accentuating desirable properties and hiding qualities that are disappointing (which are not apparent until one has some experience with the product) (Egan, 2015; Fowler \& Stern, 2015 ). Then there is a tendency to force consumers to switch by not providing upstream compatibility with connectors or programs and not providing support indefinitely. ${ }^{7}$ Microsoft often forces upgrading through frequent versions of its operating system by making older versions inaccessible and inoperative. ${ }^{8}$ Actually, that's standard practice in the industry.

\section{Conjectural Decline of ScR}

In his apotheosis of the innovating entrepreneur Schumpeter was undoubtedly thinking of the great innovations associated with steam engines, railroads, steam boats, iron, steel, petroleum, chemicals, electrification, telegraph, telephone, radios, automobiles, airplanes, film making, paper making, plastics, rubber, and machines 
and engines of all sorts. No doubt that the entrepreneurs who brought these innovations to the market did force old firms and industries out of business but surely their destructive component must have been minuscule while the gains in productivity were humongous. While theoretically the effect of innovation on employment is ambiguous (Vivarelli 2014,147 ), there was no technological unemployment in the wake of the First or Second Industrial Revolutions after an initial period of dislocation. The reason is that many of the breakthroughs were capable of capturing economies of scale previously undreamed of and thereby expanded demand astronomically including in many cases markets that were previously inaccessible. Moreover, all satisfied an innate natural need so consumers did not need any convincing to adopt the new products. The prices of industrial products fell precipitously so that the increasing demand created jobs in the millions. Many completely new products came into being and some of the discoveries brought forth general purpose technologies with substantial impact on the productivity gains of other sectors that rippled through the economy. Consequently, backward and forward linkages were immense and powerful. Most importantly, the non-mechanized firms that were destroyed were generally small-scale operations working with little capital. Hence, their destruction did not waste much capital and was not disastrous for workers either, because those displaced immediately found ample opportunities in the expanding modern sectors.

The new technologies mentioned above used labor on a massive scale so that the workers displaced by the innovations could easily find employment in the new sectors of the economy as skills were transferable across industries. Hence, the destructive force of those innovations was not only small but waned in significance relative to the creative component. Of course, this does not mean that all innovations of the past were of such momentous consequence. The point, however, is that there were numerous such epoch-defining innovations between the 18th and 20th centuries, in contrast to more recent developments in the twenty-first century. Accordingly, our conjecture is that $\mathrm{ScR}$ must have been huge, with $C \gg D$, during the two Industrial Revolutions and their aftermath.

For instance, innovations such as the incandescent bulb replaced the kerosene lamp and the value added to GDP as it was immensely superior in terms of reliability, convenience, health, and safety were humongous. The destruction of the kerosene lamp industry must have been a miniscule loss to the economy. Similarly, the telephone was a new technology that replaced nothing but the pigeon carrier and perhaps some mail. In short, these new technologies destroyed traditional non-mechanized small-scale operations so that the gains in economies of scale were gigantic. Clearly, the closer is the substitutability between the new and the old product (or the new and old ways of doing something) the higher is the negative externality likely to be. Until recently, the degree of substitutability between the new and the old products was very low or even non-existent, implying that the creative component of innovation must have been extremely large relative to the destructive component. However, that no longer appears to be the case.

\section{Creative Destruction: Past, Present and Future}

Empirical research estimating the size of the destructive power of innovation over time would be useful for understanding more fully the contribution of innovation to GDP. The goal of this note, however, is the more modest one of sketching the outlines of the problem and thereby urging others to undertake quantitative research estimating the long-run trend in ScR. It is generally acknowledged "that, on balance, the process of creative destruction is more creative than destructive, not only with regard to employment but also concerning broader perspectives of growth and welfare" (Heertje 1987 ). This was probably true until recently with innovations associated with PCs, laptops, and cell phones of the late twentieth century. However, informal observation leads us to conjecture that at the turn of the twenty-first century ScR declined markedly, because recent innovations, mostly in the IT sector, have had substantial substitution effects between the new and the old products with increasing destructive components $(C \ll D){ }^{9}$

Consequently, our conjecture is that the benefits reaped from creative destruction has declined substantially recently and is likely to remain at a low level. In other words, the net value added to GDP or to employment,- net of the negative externalities - most likely has diminished recently. The primary reason is that our innate basic needs (of food, clothing, shelter, health care) ${ }^{10}$ have been satisfied with existing technologies that are produced by firms efficiently on a large scale. Hence, new firms may be able to destroy competing firms due to a slight competitive advantage or because of novelty but nonetheless fail to increase employment or GDP significantly (Gordon 2016 ). That the growth in real per capita GDP in the twenty-first century has been $1.0 \%$ per annum in contrast to $2.8 \%$ between 1978 and $2000^{11}$ is just one indication of a general slowdown in the economy and the decline in productivity growth is an obvious suspect in this slowdown (Gordon 2016). In addition, the amount spent on convincing people to adopt the new products has also risen. 
Consider that tablet computers expanded to the detriment of laptop computers; Amazon replaced countless local bookstores as well as Borders, which in 2003 had more than 1,200 stores. Furthermore, the smartphone replaced simple cell phones and traditional cameras. The "selfie" replaced the "Kodak moment" but Kodak employed 86,000 in 1998, and 145,000 at its peak (and paid them mostly middle-class wages) (Pearlstein, 2014; Teather, 2014 ), while in 2014, after emerging from bankruptcy, it has a skeleton workforce of 8,000. ${ }^{12}$ The bankruptcy of Kodak was likely more substantial in terms of depreciation of plant and equipment than the destruction of hand-loom weavers, kerosene lamp makers, or horse-and-buggy makers combined. ${ }^{13}$

In contrast, Apple, Inc. - one of the iconic corporations of the information era, - has but 76,000 employees in the United States, most in sales earning below middle-class wages. ${ }^{14}$ No wonder the United States is experiencing a "jobless recovery". For instance, U.S. employment in the "internet publishing, broadcasting and search portals" sector increased in the fifteen years from 1999 until 2014 from 64,000 to 151,000 (or by 87,000) ${ }^{15}$; at the same time, however, the number of jobs in the newspaper publishing industry was halved from 424,000 to 212,000 with a decline of 212,000 jobs. Hence, the net loss of jobs in this process of creative destruction was around 125,000 in 15 years.

Moreover, because of the Internet revolution, many traditional newspapers are either decreasing their print edition or discontinuing them completely and going digital - including the Christian Science Monitor, with a concomitant loss of jobs. ${ }^{16}$ Many newspapers succumbed to bankruptcy such as the Tribune Company and the Sun-Times Media Group. ${ }^{17}$ With the expansion of the Internet, advertising revenue of newspapers plummeted by two-thirds of its 2001 peak of $\$ 65$ billion to $\$ 24$ billion in $2013,{ }^{18}$ while Internet ad revenues increased in the same time span from $\$ 7.2$ billion to $\$ 42.8$ billion, compensating for the amount lost to newspapers, ${ }^{19}$ with total advertising revenue remaining essentially unchanged. ${ }^{20}$

While social networking facilitated by Facebook is a popular feature of the Internet, basically it merely replaces older ways of socializing. ${ }^{21}$ It monetized activities that were for the most part previously left outside of the market's purview and provides employment to merely 12,000 people. ${ }^{22}$ Facebook's market capitalization is about $\$ 300$ Billion, and Twitter, WhatsApp, Instagram are all household names worth billions but probably add less value to real GDP and employment beyond the technologies and firms they replaced than appears on the surface. This is likely the case, because the needs they respond to were mostly satisfied prior to their existence. The efficiency gains were not substantial. They destroyed old forms of communication to which they are close substitutes; hence, our conjecture is that their $\mathrm{ScR}$ value is fairly small. Their value to downstream or upstream demand is not comparable to the disruptive effects of the steam engine, the internal combustion engine, or electric motors and their miniaturization.

The current list of "disruptive technologies" that are likely to usher in future waves of innovation include such fields as education, information, cognitive science, robotics, artificial intelligence, pharmaceuticals, and nano- and biotechnology including genetic engineering. These are not likely to offer major new consumer goods which make up the largest part (70\%) of the U.S. economy and even those that might be forthcoming promise will likely satisfy a need that is already satiated and they will replace products that are already produced efficiently like Windows 10 replaced Windows 8 (skipping version 9) without measurable gains in efficiency. Therefore, it seems like the innovations of the foreseeable future will probably not create substantial net gains in GDP or employment; rather, they will be mostly close substitutes for already existing technologies implying that $C-D$ will be probably relatively small, as with "Google Glass", the driverless car, or drone delivery. These might even become useful in some circumstances but do not promise great gains in employment or GDP growth. After all, Google glass is going nowhere and the driverless car will put truck and taxi drivers out of business while drone delivery will do the same to drivers of delivery trucks. Similarly with genetic engineering: it might be able to increase life expectancy but it is doubtful that it will add measurably to GDP per capita. These are comparable to the effects on our lives of such disruptive innovations as the airplane, the radio, or the vacuum cleaner. After all, the latter along with numerous other efficiency inducing household products enabled the entrance of millions of housewives into the labor force.

Thus, we conjecture on the basis of this impressionistic evidence relating to the nature of recent technological developments, that creative destruction by the twenty-first century is deviating markedly from its previous manifestations insofar as its ScR value seems to have declined conspicuously. This implies that the contribution of the innovation to employment will be small and its impact on GDP growth will likely be modest and overestimated insofar as the accounts fail to account accurately for the negative externalities caused by the destructive forces of creative destruction.

Although this essay focuses on major innovations rather than on incremental qualitative improvements, those are also worthy of considerations. The official statistics uses hedonic price estimates in order to value the changes in quality of a product. The use of hedonic pricing leads to a substantial decline in the price of products characterized by rapid changes in technical characteristics. ${ }^{23}$ For example, the Bureau of Labor Statistics estimates that the price of television services has declined from and index number of 105 to 6 between 1980 and $2011 !^{24}$ This seems highly exaggerated insofar as the price of color televisions in the 70s and 80s was somewhere 
in the \$400-\$1,400 range. ${ }^{25}$ Not very different from what today's television sets cost. If the 17.5 ratio were accurate one would be able to buy a decent new television for $\$ 22$ but such televisions are not available. To be sure, the argument is that today's televisions are smart, have more bells and whistles; have more pixels and more channels. But the other side to this argument is that people are buying entertainment services by watching television and they still normally watch one channel at a time and they likely do not obtain more satisfaction out of watching that channel than they did in 1980. At least I do not know of any evidence that would indicate that people are getting more satisfaction out of televisions watching now than they did decades ago. Most importantly, since the various features of the television set are bundled, consumers do not have the choice to pick the ones they prefer. Insofar as the old system is no longer available, the consumer is forced to use the new televisions. If the consumers do not have a choice between the old and new, the assumptions associated with the use of hedonic prices do not apply in practice, and hedonic regressions do not reflect accurately consumers' willingness to pay for those features. ${ }^{26}$

In addition, in 1980 one did not have to pay at all for watching TV. Now people in the United States do (Leichtmann Research Group 2016 ). Aside from introductory offers, basic cable services cost about $\$ 64$ per month or $\$ 768$ per year. ${ }^{27}$ Such expenses did not exist in 1979 so they make it much more difficult for many households to maintain a middle-class living standard that they were capable of doing a generation ago. So the incorporation of such hedonic price indexes into the consumer price index biases the cost of living as it is actually experienced in the downwardly direction: they make it appear as though price increases are less than they actually are.

In addition, many qualitative changes are deceptive: they appear to be improvements but have non-essential features that are not practical enhancements: "the question [is] whether a novelty is an improvement: the world may not be getting better and better but our devices are getting newer and newer" (Lepore 2014 ). In short, quality is very difficult to measure and the impression gained from the official price data is that our living standards have increased by more than our subjective assessment.

\section{Bite-Backs}

We have been discussing the immediate destructive negative externalities of innovation but there are long-term ones as well which are not immediately evident. Joel Mokyr, the distinguished historian of technology, who is generally optimistic about future developments (Mokyr, Vickers, and Ziebarth 2015 ), nonetheless acknowledges that technological change is by no means a free lunch; one needs to consider the "bite-backs" as well: "most technologies developed in the twentieth century had unanticipated side effects, most of them negative" (Mokyr 2014 ). Of course, this is not what Schumpeter had in mind with destructive forces, nonetheless, innovations such as DDT, chlorofluorocarbons, carbon fuels, leaded gasoline, fast food, asbestos, and lead-based paint all generated major negative externalities whose true costs were discovered long after they were implemented and therefore created an illusion of productivity increases. "It is thus now plain we have overestimated the productivity gains associated with technological change in the twentieth century" (Mokyr 2014 ). "This means the social costs of new techniques (as opposed to the costs captured in market prices) are systematically underestimated" (Mokyr 2014 ). He suggests that such unanticipated costs are "very common; indeed, it is hard to come up with examples of a major breakthrough in technology in which it was not later realized that the accompanying 'creative destruction' included some of the uncreative sort. Unfortunately, correcting national income calculations to account for such effects is difficult" (Mokyr 2014 ). Nonetheless, economists should begin estimating all the negative externalities including the value of these "bite-backs" (such as global warming) in spite of the obvious challenges of doing so retrospectively. That would give us a much better sense of the contribution of innovation to economic performance and improve our ability to frame policy in the future.

\section{Innovation as Rent Seeking}

There are many other unresolved issues surrounding the effects of innovation that need to be explored further. For instance, not all innovation enhances productivity as many are designed for rent seeking purposes (Akerlof \& Shiller, 2015; Heidhues, Köszegi \& Murooka, 2016 ). That is also Paul Volcker's assessment of the innovations associated with the financial crisis: in his view the only financial innovation that raised productivity was the automated teller machine (ATM) and that was a product of mechanical engineering designed in the 1960s in Great Britain and not on Wall Street. ${ }^{28}$ The myriad of so-called financial innovations culminated in an immense "bite-back" which threatened the global economy and had to be propped up with $\$ 7$ trillion support from 
the government in the United States alone and an annual loss in output in the United States of more than \$1 trillion. ${ }^{29}$

Consider moreover, that Uber, founded in 2009 as a mobile ride request company, has a market capitalization of some $\$ 62$ billion which is greater than that of Ford Motor Company. ${ }^{30}$ Its success is based primarily on extracting economic rents that exist in the taxi business. The gains in productivity associated with the firm are slight but it destroys taxi drivers' jobs and incomes. Net gains are slight.

Pharma companies also use several strategies to extend their monopoly rents on their patented drugs in the guise of innovation. They protect their market share by patenting new ways to administer a known compound that can demonstrate some advantages such as reduced dosage or ease of use. For instance, Eli Lilly extended its patent on Prozac that had to be taken just once a week, thereby extending its ability to gain monopoly rents from the sale of the antidepressant drug (Gupta et al. 2010 ). Minor changes in formulations can also extend a drug's patent as can new uses different from the one originally patented. Another creative way to defend monopoly rents is to combine two drugs into one tablet and apply for a new patent. Such strategies have more to do with rent seeking than with Schumpeterian innovation.

\section{Innovation and Pareto efficiency}

Another neglected controversial aspect of technological change is that it is not at all democratic, insofar as entrepreneurs impose their will on the society without a popular mandate and thereby dictate the redistribution of income without consent of those who are affected by their product. In other words, they generate negative externalities that are not compensated. They can afford to hire celebrities to sing the praises of their products and build customer loyalty through emotional branding. ${ }^{31}$ Once rich and famous begin to buy their products many people follow suit either through peer pressure or in order to "keep up with the Joneses". Hence, the process is hardly democratic insofar as the public is not asked in a referendum whether it wants the new technology or at what rate it would like to transition to the new technology. It is not asked whether we should allow the destruction of the existing technologies and the concomitant misery of those whose labor is rendered superfluous by the innovation. Technological change is not only undemocratic, it is also not "Pareto efficient"as Schumpeter himself recognized (Schubert 2013 ). "Schumpeterian change ... tends to come with harmful side-effects for a subset of the individuals involved (Schubert 2015,13$)$ )." The harmful effects obviously include the loss of income but also "increased uncertainty, anxiety, devaluation of human capital, dislocation, status losses, etc. An innovative economy may be an 'uncomfortable system in which to live (Schubert 2015 , 13)." In addition, the political implications of that discomfort have been disregarded until recently. However, with the threatening rise of Trumpism we have belatedly come to the stark realization that creative destruction can also have very severe political consequences. ${ }^{32}$

The often invoked Kaldor-Hicks efficiency criterion is useless in this regard inasmuch as the losers are never adequately compensated either by the winners or by the society. Another weakness of the Kaldor-Hicks criterion is that in practice it is conceived in monetary terms and not in terms of utility which should be the criterion used in terms of the compensation principle. The reason why this is relevant is that while the monetary gains of the gainers may far exceed that of the monetary losses of the losers, the arithmetic in terms of utility may well be reversed. This is the case inasmuch as the diminishing marginal utility of income implies that if the gains accrue to the wealthy and the losses to the poor the utility of the wealthy might increase by a small amount while that of the poor might decrease by substantially more.

Furthermore, it is contradictory to celebrate such a process when it pertains to innovation even though it is not Pareto efficient while at the same time economists generally argue against the government redistributing income for exactly the same reason, i. e., that the redistribution is not Pareto efficient (Witt 1996 ). From what derives this privilege of entrepreneurs to be exempt from the Pareto principle when such exemptions do not accrue to the state?

This is a major incoherent aspect of economic theory and economists should think about laws and institutions that will defend the rights of those who are at risk of being hurt. The immense destructive forces of the financial innovations of the late-twentieth century should provide a powerful incentive to develop institutional mechanisms to assess the riskiness of innovations and to foster Pareto-improving innovations (Witt 1996 ). The FDA tests drugs before they can be used commercially; there is no reason why we cannot test other products for their side effects in order to be able to make informed choices about their desirability ${ }^{33}$ (Offer 2006 , 35).

For instance, several European countries have come to the rescue of local bookstores by limiting the amount of discount Amazon is allowed to grant as a defense mechanism of Amazon's destructive forces. ${ }^{34}$ The State of Massachusetts is discussing taxing ride-hailing companies in order to compensate taxi providers. ${ }^{35}$ Another example comes up in English common law in which the owner of a building with windows that has had natural 
daylight for at least 20 years enjoys a "right to light" so that new construction is not allowed to impinge upon it. $^{36}$ This is an example of "Pareto-optimal" growth that should be more widely adopted. Witt does suggest that we should innovate in such a way as to minimize the destructive consequences of innovation (Witt 1996 ).

\section{Prognosis for Growth}

The conjecture expressed in this essay dovetails with several pessimistic prognoses of the future of the U.S. economy insofar as many prominent economists are arguing that economic growth is going to be slow as far as the eye can see (Gordon, 2016; Vijg, 2011 ). Mokyr also notices that "a wave of pessimism has swept the economics profession - with many analysts concluding that the best is behind us, i. e., that the low-hanging fruits of technology have been picked and that we can no longer replicate the enormous technological successes attained [in the past]" (Mokyr 2014 ). According to scholars such as Larry Summers (Harvard), Robert Gordon (Northwestern), Nobel-Prize winning economists Paul Krugman (Princeton), and Joseph Stiglitz (Columbia) the post-industrial service economy is going to be stuck in low gear for the foreseeable future,-at least for $99 \%$ of the population. ${ }^{37}$ The arguments of these scholars recognize a number of impediments to growth including: tenacious political dysfunction (Krugman) ${ }^{38}$ inadequate aggregate demand (Summers), ${ }^{39}$ pervasive inequality (Stiglitz) ${ }^{40}$ and an array of structural problems which lead to slow productivity growth (Gordon). ${ }^{41}$

Gordon calculates that labor productivity growth slowed after 2004 to $0.76 \%$ per annum - roughly a third of what it was throughout the twentieth century and he is not alone in making such assertions (Fernald, 2014; Fernald \& Wang, 2015 ). This is another reason to be pessimistic about our future prospects, and forecasts that the real disposable per capita income of the bottom $99 \%$ of the income distribution will grow at a negligible rate of $0.2 \%$, that is to say, it will be difficult to distinguish it from utter stagnation (Gordon 2012, Gordon 2014, and Gordon 2016 ). ${ }^{42}$

Although Tyler Cowan (George Mason) as well as the team of Brynjolfsson and McAfee (MIT) retain their basic optimism, they admit that technological unemployment will be with us permanently unless U.S. enacts far-reaching policies to reform our educational system to counter those tendencies ${ }^{43}$ (Brynjolfsson \& McAfee, 2012; Brynjolfsson \& McAfee, 2014; Cowan, 2011; Cowan, 2013 ). This bears some similarity to Pasinetti's argument: "with technological progress, the economic system inevitably generates unemployment, if in the meantime nothing else occurs, or only occurs with insufficient speed $(1993,54)$ ". An increase in leisure, for instance, can compensate for the labor-saving effects of technological change suggests Pasinetti, but he continues in a nottoo-reassuring tone that there is "a permanent problem of coordination ... [and a] challenging task of pursuing the macro-economic goal of an adequate global effective demand and full employment $(1993$, 59)."

In a similar tone, Vivarelli concludes that the extent of technological unemployment is a matter of empirical evidence and not of theory: "since economic theory does not have a clear-cut answer about the employment effect of innovation, there is a strong need for aggregate, sectoral, and microeconomic empirical analysis, able to account for technological change, its direct effects on labor, compensation mechanisms, and possible hindrances to these mechanisms ${ }^{44}$ (Vivarelli 2014 , 46-147)."

Brynjolfsson and McAfee also argue that technological change has advanced to such a high level, that the economy needs fewer workers to sustain production, leading to a "jobless recovery". Since the Meltdown of 2008 the employment/population ratio has declined by some 5 percentage points and $10 \%$ of the labor force is still underemployed 8 years after the start of the recession. ${ }^{45}$ This is evidence that GDP growth has been decoupled from employment, insofar as firms switched from human labor to robot labor. In other words, people are becoming increasingly redundant through automation and endemic underemployment is going to persist for the conceivable future (Brynjolfsson and McAfee 2012 ). Actually, nearly a half of all U.S. employment is at risk of becoming redundant through computerization (Frey and Osborne 2013 ).

The discussion so far has been mostly in terms of GDP and employment which is conventionally casually equated with living standards. However, ultimately economists should be more interested in the welfare of the population than in GDP inasmuch as it is, after all, a crucial variable of interest in applied economic analysis. Generally conventional analysts assume that the utility function is exogenously given and immutable but of course in a Schumpeterian world that cannot be the case inasmuch as preferences change all the time as new products come into the market so that the utility function becomes endogenous ${ }^{46}$ (Schubert 2012, Schubert 2013, and Schubert 2015 ). Endogenous tastes contradict the oft touted principle of consumer sovereignty, namely, that consumers purchase what satisfies their utility function. In reality, producers influence consumers' desires so that they will want what the producers determined to produce. They accomplish this by appealing to consumers' emotion and subconscious through their advertisement campaigns (Komlos 2014 ).

In such an evolutionary economy the relationship between income and welfare is more complex than conventionally assumed and most likely explain why the happiness index - a proxy variable for welfare or life 
satisfaction - has not increased at all in the United States since World War II although real GDP per capita increased amazingly by a factor of 3.8 (Easterlin 2015 and Easterlin 2016 ). ${ }^{47}$ The stagnating life satisfaction might be a reflection of the fact that as new products come into the market, they devalue the ability of existing products to generate utility and create new needs whose satisfaction requires renewed effort. However, satisfaction is continuously interrupted as new needs are incessantly created. In a short time we adapt to the new products - we get used to them - so that they fail to satisfy and we aspire to more; so in this way satisfaction continues to elude the modern consumer.

\section{Conclusion}

This essay focuses on the destructive components of innovation which is mostly disregarded in mainstream discussion. The hypothesis is advanced that creative destruction has become more destructive recently relative to its creative component. Yet, today's culture adores the "gospel of innovation" without acknowledging forthright the deleterious effects of its concomitant negative externalities or caring much about the suffering they cause (Lepore, 2014; Stiglitz, Sen \& Fitoussi, 2010 ). In fact, "disruptive innovation" is celebrated to such a degree that it tends to "glamorizes business" (Krugman 2014 ).

Actually, creative destruction is being taken to a new level: "devastating innovation" with no consideration of how much of it will improve the human condition and how much damage its spillover effects cause. The transition to a post-industrial economy has been far from advantageous to the well-being of a substantial share of the population. Just because the U.S. population has been innovating and growing successfully for a quarter of a millennium by no means implies that the process will, or should, continue indefinitely. No such economic theorem exits and the historical record indicates that there are times when economic regimes do reach a tipping point and abruptly change direction. We may well be at the threshold of such a "new normal".

Nonetheless, there are still many optimistic voices. "As has been true now for more than two centuries, technological advance will continue to improve the standard of living in many dramatic and unforeseeable ways (Mokyr, Vickers, and Ziebarth 2015,47)." In support of their assertion, however, the optimists have little to offer beyond the vague suggestion that predictions of a slow-down in technological change have been wrong in the past so they will prove to be wrong again. ${ }^{48}$ Yet, that is a classic non-sequitur. The historical record is replete with regime changes including the Neolithic Agricultural Revolution, the end of Feudalism, the Industrial Revolution, the onset of modern economic growth as well as the disappearance of the Roman Empire with all its mesmerizing technology including the aqueducts, civil engineering and architecture based on innovations in cement and concrete. In contrast, many believe the developed economies of the West is now witnessing the end of an era that was inaugurated a quarter millennium ago by the Industrial Revolution and the beginning of a new epoch that has been dubbed the post-industrial age, the knowledge economy, or the information age with a dominant service sector. ${ }^{49}$ However, productivity-enhancing innovation in this era is going to be much slower as Gordon (2016) has convincingly argued.

So there are adequate reasons to remain skeptical about the arguments of the optimists based on wishful thinking or the non-sequitur that this time cannot be different from previous experience. Many scholars are doubtful about our ability to continue on the path forged since the First and Second Industrial Revolutions. This time is most likely going to be different: the West seems to have reached an upper bound on its ability to increase the income of those who are already at the technological frontier. The new technologies might well be brilliant and create immense wealth for a few, thereby continuing to exacerbate socio-economic inequality and exclude an ever increasing share of the population from the middle class with dire political consequences (Wolf 2016; Komlos 2016a and Komlos 2016b ). Yet, the numbers of underemployed and working poor will probably continue to swell (Brynjolfsson and McAfee 2014 ). It is more than likely that the West has entered an age of a new normal (Galbraith 2014 ) that will resemble more closely the social structure of the ancien regime than that of an ephemeral ideal democratic economy (Piketty 2013 ). This essay adds another dimension to this conjecture, namely that there has been a shift in the destructiveness of new technologies and this effect has so far not been captured adequately in the economic statistics that are used to gauge the performance of the economy and to formulate an adequate policy response. This essay calls for empirical research in order to explore this conjecture.

In sum, the hypothesis advanced in this essay is that the new technologies that are being created bring about larger negative externalities than in previous epochs by forcing the early and premature obsolescence of products and firms they destroy. Innovation's net value added to GDP or employment,-net of the negative externalities - has most likely diminished substantially in the twenty-first century. The destructive forces of creative destruction have gained the upper hand. Moreover, these negative externalities are not adequately understood by the public, by policy makers, or by the media so that the contribution of the innovation to GDP and to employment is overvalued. This is the case, we have argued, because the destructive power associated 
with Schumpeterian creative destruction has increased markedly relative to its creative component, in stark contrast to previous epochs. With desperate innovations such as Google glass, Apple watch, Windows 8 and 10 , or iphone 6, creative destruction's gentle winds have mutated into cyclones of destruction. Thus, our life satisfaction will probably not keep pace with even the slow economic growth being predicted by Gordon and Summers. While the economy will be growing, albeit slowly, our sense of well-being will be mysteriously lagging well behind, unless the developed world is able to tame the destructive forces of Schumpeter's gale. ${ }^{50}$ And given the kind of innovations in the pipeline this trend is most likely to continue.

\section{Acknowledgement}

I appreciate comments from Michael Asch, Fiona Atkins, Dean Baker, Stuart Birks, Art Carden, Lawrence Cima, David Colander, Lee Craig, Charles Dannreuther, Wolfram Elsner, Gerald Friedman, Michael Ghiselin, Nick Kahn, Janos Kornai, Edward Leamer, John R. McNeill, Avner Offer, Barry Schwartz, Christian Schubert, Claire Smith, Peter Söderbaum, Paul C. Sutton, and Ulrich Witt as well as the editor of this journal and two anonymous referees on a previous version of the paper. They are obviously not responsible at all for any possible omissions or commissions that might remain.

\section{Notes}

${ }^{1}$ This is also true of new capital investments as an addition to the capital stock without innovation may cause some of the existing capital stock of others to depreciate.

${ }^{2}$ Davis et al. measure job flows between new and old job descriptions and find that $10 \%$ of jobs is created and destroyed annually. However, the study was limited to manufacturing and changes in job description do not necessarily imply creative destruction (Davis, Haltiwanger, and Schuh 1996 ).

${ }^{3}$ Depreciation in the National Income and Product Accounts are based primarily on magnitudes reported by corporations to the Internal Revenue Service. Bureau of economic Analysis, 1998 "A Guide to the NIPA's," Survey of Current Business March.

http://www.bea.gov/scb/account_articles/national/0398niw/maintext.htm. I am grateful to Lisa Lynn of the Bureau of Economic Analysis for explaining the intricacies of the depreciation estimates.

${ }^{4}$ For instance, while Microsoft's XP operating system probably had a higher value added, its successor, the Vista version was less successful and its ScR was probably tiny or negative. Same can be said of Windows 8 over the previous version.

${ }^{5}$ Apple is notorious for predatory strategies to ensnare customers. When we buy an iphone we are not informed when the next version will be released. A new generation of iphones makes the previous version unfashionable and manipulates many consumers out of their equilibrium. The depreciation that the new version induces in the current value of iphones is unanticipated and is also not subtracted from GDP, i. e., GDP increases with the full value of the new iphone when it is sold while our well-being does not increase proportionally insofar as the old model's value is destroyed.

${ }^{6}$ I cannot count the number of times I have been pestered by Microsoft to upgrade to its Windows 10 operating system.

${ }^{7}$ According to Avner Offer, "the process of constant upgrading means that users never have time to master the software, and are therefore stuck permanently at the bottom of the learning curve, thus deriving less welfare than the innovation is capable of delivering." Personal communication.

${ }^{8}$ The fashion industry is another example of a sector in which new products mostly replace existing products for which they are close substitutes and which would not have been devalued had it not been for the creation of the new products (Veblen 1899 ). The creation and promotion of new fashion renders part of our inventory of clothing obsolete. That implies that we do not obtain as much utility from the clothing we now have as we anticipated at the time of purchase. We are not told how long a particular fashion will last. The new fashion suddenly and unexpectedly depreciates the value of the old but because they are close substitutes ScR is probably small: The fashion industry has a large destructive component but it is big business with $\$ 250$ billion annual sales in the United States and $\$ 1.2$ trillion world-wide. Hence, its contribution to the mis-measurement of GDP is likely to be substantial and likely increasing as the products of fashion have become a bigger part of our expenditure (Statistic Brain 2014 ).

${ }^{9}$ This assertion is conjectural and should be tested in subsequent empirical research.

${ }^{10}$ Although mainstream economics considers demand exclusively in terms of "wants," it is essential to consider goods that fulfill basic survival needs, such as food in sufficient quantities to avoid hunger, safe drinking water to relieve thirst, shelter that includes sanitation facilities, clothing appropriate to the weather conditions, and appropriate medical care as distinct from other wants. The point is that we would not be able to live without these goods and services for long. These are innate to humans as biological organisms and not as social beings. Even the ultra-conservative economist Friedrich Hayek admitted their existence: "Very few needs indeed are 'absolute' in the sense that they are independent of social environment or of the example of others, and that their satisfaction is an indispensable condition for the preservation of the individual or of the species (Hayek 1961 )." Sure, they are small in number but extremely important nonetheless.

${ }^{11}$ Reserve Bank of St. Louis, https://research.stlouisfed.org/fred2/series/A939RX0Q048SBEA accessed September 3, 2016.

${ }^{12}$ Wikipedia, “Eastman Kodak," https://en.wikipedia.org/wiki/Eastman_Kodak\#cite_note-66 accessed June 4, 2014.

${ }^{13}$ Kodak Park is being converted to other uses. It would be useful to calculate how much value was destroyed in the bankruptcy of the firm. Wikipedia, “Eastman Business Park," https://en.wikipedia.org/wiki/Eastman_Business_Park accessed June 17, 2014.

${ }^{14} \mathrm{http}: / /$ www.apple.com/about/job-creation/ accessed January 31, 2016.

${ }^{15}$ Bureau of Labor Statistics, Current Employment Statistics Survey, Series ID: CES5051913001 and CES5051111001 http://www.bls.gov/ accessed June 3, 2014.

${ }^{16}$ Wikipedia, “Creative Destruction," https://en.wikipedia.org/wiki/Creative_destruction\#cite_ref-pifrontpage_22-0 accessed June 4, 2014.

${ }^{17}$ Wikepedia, “Decline of Newspapers,” https:/ /en.wikipedia.org/wiki/Decline_of_newspapers accessed June 4, 2014. 
${ }^{18}$ Newspaper Association of America, http://www.naa.org/Trends-and-Numbers/Newspaper-Revenue/Newspaper-Media-IndustryRevenue-Profile-2013.aspx accessed June 4, 2014. Wikepedia, “Decline of Newspapers," https://en.wikipedia.org/wiki/Decline_of_newspapers accessed June 4, 2014

${ }^{19}$ Interactive Advertising Bureau, "IAB internet Advertising Revenue Report," http://www.iab.net/media/file/resources_adrevenue_pdf_IAB_PWC_2001Q4.pdf accessed June 8, 2013; Interactive Advertising Bureau, "2013 Internet Ad Revenues Soar To \$42.8 Billion," http://www.iab.net/about_the_iab/recent_press_releases/press_release_archive/press_release/pr-041014 accessed June 8, 2013.

${ }^{20}$ Interactive Advertising Bureau, "IAB internet advertising revenue report." http://www.iab.net/media/file/IAB_Internet_Advertising_Revenue_Report_FY_2013.pdf, p. 20, accessed June 8, 2014.

${ }^{21}$ Similarly, Starbucks must have added little value to the economy over traditional coffee makers.

${ }^{22}$ Employment numbers are as of September, 2015. Wikipedia, "Facebook," https://en.wikipedia.org/wiki/Facebook accessed January 29, 2016 It is not at all obvious that the use of Facebook increases our sense of well-being: "What do you post to Facebook? Pictures of yourself yelling at your kids, or having a hard time at work? No, you post smiling photos of a hiking trip with friends. You build a fake life - or at least an incomplete one - and share it. Furthermore, you consume almost exclusively the fake lives of your social media" friends. "Unless you are extraordinarily self-aware, how could it not make you feel worse to spend part of your time pretending to be happier than you are, and the other part of your time seeing how much happier others seem to be than you?" Arthur C. Brooks, "Love People, Not Pleasure," The New York Times July 18, 2014 http://www.nytimes.com/2014/07/20/opinion/sunday/arthur-c-brooks-love-peoplenot-pleasure.html?emc=edit_th_20140720\&nl=todaysheadlines\&nlid=48226764\&_r=0 accessed August 1, 2014.

${ }^{23}$ Accordingly one estimate puts the decline in the price of television using a hedonic index at $21 \%$ just within four years in the mid-1990s (Moulton, LaFleur, and Moses 1998 , Table 5).

${ }^{24}$ I would like to thank Sharon Gibson of the BLS for providing this information.

${ }^{25}$ Television History http:/ / www.tvhistory.tv/tv-prices.htm, accessed January 31, 2016.

26 "This [hedonic regression model] uses television observations... and provides an estimate of the value of each of the significant features and components of the sets for which prices are collected. This yields a mechanism for replacing obsolete televisions in the CPI sample with current ones ..." (Bureau of Labor Statistics 2016 ).

${ }^{27}$ Without taxes or other fees. http:/ / www.ehow.com/about_5385381_average-cable-tv-per-month.html, accessed January 30, 2016.

28 "Paul Volcker: Think More Boldly," The Wall Street Journal, December 14, 2009, http://online.wsj.com/news/articles/SB10001424052748704825504574586330960597134 accessed June 29, 2014.

${ }^{29}$ Moreover, the rise in the financial sector can hinder productivity growth in other sectors by attracting highly skilled employers at the expense of the R\&D intensive industries of the real economy (Cecchetti and Kharroubi 2015 ).

${ }^{30} \mathrm{http}$ :/ / www.businessinsider.com/uber-valuation-vs-market-cap-of-publicly-traded-stocks-2015-12 accessed January $29,2016$.

${ }^{31}$ Michael Jordan is now a billionaire through his "Air Jordan" endorsements for Nike and subsequent investments.

${ }^{32}$ Martin Wolf, "Capitalism and democracy under strain," Financial Times, August 30, 2016.

${ }^{33}$ We should also identify innovations that do not add to GDP but are designed for rent-seeking purposes or for purposes of deceiving consumers (Akerlof \& Shiller, 2015; Heidhues, Kőszegi \& Murooka, 2016 ).

${ }^{34}$ Pamela Druckerman, "The French Do Buy Books. Real Books," The New York Times July 9, 2014, accessed http://www.nytimes.com/2014/07/10/opinion/pamela-druckerman-the-french-do-buy-books-real-books.html?emc=edit_th_20140710\&nl=to-

daysheadlines\&nlid=48226764 July 12, 2014. Similarly Germany moved to protect taxi drivers from internet based innovations. Reuters. "German courts uphold ban on Uber ride-share service." http://www.reuters.com/article/email/idUSKCN0HL23320140926 accessed October 3, 2014

${ }^{35}$ Reuters, "Massachusetts to tax ride-hailing apps, give the money to taxis," August 19, 2016, http://www.reuters.com/article/usmassachusetts-uber-idUSKCN10U1ST accessed, September 3, 2016.

${ }^{36}$ I thank Lee Craig for pointing this out. Wikipedia, "Right to Light," http://en.wikipedia.org/wiki/Right_to_light accessed August 1, 2014.

${ }^{37}$ For an economic model of secular stagnation, see Eggertsson and Mehrortra (2014)

${ }^{38}$ Krugman has characterized the current state of the U.S. economy as one stuck in a "low-level depression" although he thinks that in the long run it would be possible to extricate ourselves from these doldrums if the political system could function properly and adopts Keynesian expansionary policies (Krugman 2012 ). While this prescription seems theoretically plausible, there is no political leader or political movement on the horizon that could overcome the immense momentum of path dependence such as experienced by many other states facing similar predicaments. Theoretically, Louis XVI could have transformed his monarchy into a well-functioning constitutional system but the vested interests and the limitations of his own imagination were powerful enough to prevent such drastic departure from the status quo (Olson 1984 ). Today's vested interests are just as powerful and just as dogmatically opposed to the modernization of the political-economic system. In addition, intellectual succor is provided for them by economists who are staunch opponents of progressive policies. So the political stalemate is a mirror image of the stalemate in the economics profession. That implies that political systems can become trapped in a dead end with no feasible exit within the established legal framework and ideological structure.

${ }^{39}$ Larry Summers' advocacy of the "secular stagnation" thesis is significant, because in earlier pronouncements, especially while he was in the administration, he projected much more optimism about the shape of things to come. He now argues convincingly that "something is a little bit odd" about the performance of the U.S. economy in the twenty-first century. He noticed that in spite of the easy-money policy of the Federal Reserve, the explosion of debt as people withdrew their savings from their home equity, the "vast amount of imprudent lending", and consumers giddy from a false impression that they were wealthy "in excess of its reality", the economy was by no means growing as rapidly as one would expect in a boom. Summers concludes that in spite of all these factors that should have fueled aggregate demand, "Capacity utilization wasn't under any great pressure. Unemployment wasn't under any remarkably low level. Inflation was entirely quiescent. So somehow, even a great bubble wasn't enough to produce any excess in aggregate demand" (Summers 2013, Summers $2014 a$, and Summers 2014b ). According to Krugman this was a "very radical manifesto," as Summers is really saying that "we may be an economy that needs bubbles just to achieve something near full employment - that in the absence of bubbles the economy ..." will continue to falter (Krugman 2013 ). In short, Summers is suggesting that the US economy has morphed into a regime of mediocre performance.

${ }^{40}$ Joseph Stiglitz has identified the pervasive and growing inequality in the United States as a major culprit in the weak macroeconomic performance (Stiglitz 2012 ).

${ }^{41}$ Gordon cites a number of "headwinds" that gives rise to this slowdown including the mediocre educational system that fails to equip the labor force with sufficient human capital and the extremely skewed distribution of income which keeps purchasing power out of the hands of those who would like to spend and puts them into the hands of those who have nothing more to spend on (Gordon 2012 and Gordon 2014 ). Just one indication of the low efficiency of the educational system note that even those with a college degree in the U.S. score well below average of the scores obtained in mathematics proficiency and in reading by students in advanced industrialized countries (Carey 2014 ).

${ }^{42}$ Of course, the various factors impeding future growth are interrelated because people with an inadequate education are not going to be employable in the IT sector. Hence, the poorly educated are most likely to be at the mercy of technological unemployment and join the 
ranks of the unemployed fueled by globalization and competition with low-wage labor in Asia but then are most likely to be manipulated by demagogue politicians. Josh Hafner, "Donald Trump loves the 'poorly educated' - and they love him," USA TODAY February 24, 4016,

${ }^{43}$ What they fail to see, however, is that the current unbalanced educational system is regrettably cast in stone unless the United States were somehow able to redistribute income on a very large scale which remains a pipedream utterly contrary to the spirit of the age.

44" possible hindrances to compensation mechanisms may only allow partial compensation, depending on institutional settings and on the values of crucial parameters, such as demand elasticity, degree of competition, capital-labor substitution, demand expectations."

${ }^{45}$ Federal Reserve Bank of St. Louis, https://research.stlouisfed.org/fred2/series/U6RATE accessed January 30, 2016.

46 "GNP is not a measure of economic welfare... . Economists all know that, and yet their everyday use of GNP as the standard of measure of economic performance apparently conveys the impression that they are evangelistic worshippers of GNP (Nordhaus and Tobin 1973 , 512)."

${ }^{47}$ St. Louis Federal Reserve, https:/ / research.stlouisfed.org/fred2/series/A939RX0Q048SBEA accessed February 4, 2014.

${ }^{48}$ "There is an underappreciated growth in the tools available for science and technology researchers. Across the sciences extraordinary large amounts of data can now be stored and searched. New findings can rapidly be transmitted across the global networks of science and research.... One field that has been particularly affected by the development of new tools is genetics... We also expect that competition between firms, nations, and major trading blocs will stimulate continued efforts at technological gains (Mokyr, Vickers, and Ziebarth 2015, 47)."

${ }^{49}$ Information overload of the human brain also sets limits on what can be accomplished with all the knowledge created.

${ }^{50}$ While Stevenson and Wolfers have argued that life satisfaction is continuing to increase, Easterlin has shown the flaws in their analysis and demonstrates that the happiness index in the United States has been declining for decades (Easterlin 2015 , Figure 13.8, 2016 , Figure 2; Stevenson and Wolfers 2013 ).

\section{References}

Aghion, P, and P Howitt. 1998. Endogenous Crowth Theory. Cambridge, MA: MIT Press.

Akerlof, G, and R Shiller. 2015. Phishing for Phools: The Economics of Manipulation and Deception. Princeton: Princeton University Press.

Brynjolfsson, E, and A McAfee. 2012. Race Against the Machine: How the Digital Revolution is Accelerating Innovation, Driving Productivity, and Irreversibly Transforming Employment and the Economy Digital Frontier Press.

Brynjolfsson, E, and A McAfee. 2014. The Second Machine Age: Work, Progress, and Prosperity in a Time of Brilliant Technologies. New York: Norton.

Bureau of Labor Statistics. Using a Hedonic Model to Adjust Television Prices in the Consumer Price Index for Changes in Quality 2016. Accessed January3o. http://www.bls.gov/cpi/cpiheo1.htm.

Carey, K Americans Think We Have the World's Best Colleges. We Don't. The New York Times 2014. Accessed June 29 2014. http://www.nytimes.com/2014/06/29/upshot/americans-think-we-have-the-worlds-best-colleges-we-dont.html?emc=edit_th_20140629\&nl=todaysheadlines\&nlid=48226764.

Cecchetti, S, and E Kharroubi. 2015. “Why Does Financial Sector Growth Crowd Out Real Economic Crowth?” Bank of International Settlement, Working Papers no. 490.

Cowan, T 2013. Average Is Over: Powering America Beyond the Age of the Great Stagnation. New York: Dutton.

Cowan, T 2011. The Great Stagnation: How America Ate All the Low-Hanging Fruit of Modern History, Got Sick, and Will (Eventually) Feel Better. New York: Dutton.

Davis, S, J Haltiwanger, and S Schuh. 1996. Job Creation and Destruction. Cambridge, MA: MIT Press.

Easterlin, R. A 2015. “Happiness and Economic Growth - The Evidence." In Clobal Handbook of Quality of Life, edited by W Glatzer, L Camfield, V Moller, and M Rojas, 283-299. Dordrecht: Springer.

Easterlin, R. A 2016. “Paradox Lost?".

Egan, T 2015. “Digital Dog Collar." The New York Times. March13.

Eggertsson, G, and N Mehrortra. 2014. "A Model of Secular Stagnation." Working Paper. Department of Economics, Brown University.

Fernald, ] 2014. "Productivity and Potential Output Before, During, and after the Great Recession." In NBER Macroeconomics Annual 2014, edited by J Parker, and M Woodford, Vol. 291-51.

Fernald, J, and B Wang. 2015 (February) 9. "The Recent Rise and Fall of Rapid Productivity Crowth." Federal Reserve Bank of San Francisco Economic Letters, no. 4. February9.

Fowler, G. A, and J Stern. 2015 (March) 10. “The 12 Tech Nuisances That Annoy Us Most.” The Wall Street Journal. March10.

Frey, C. B, and M. A Osborne. 2013 The Future of Employment: How Susceptible are Jobs to Computerisation?. University of OxfordUnpublished Manuscript,http://www.oxfordmartin.ox.ac.uk/downloads/academic/The_Future_of_Employment.pdf.

Fromm, E 1955. The Sane Society. London: Routledge.

Galbraith, J. K 2014. The End of Normal. The Great Crisis and the Future of Growth. New York: Simon and Schuster.

Cordon, R 2016. The Rise and Fall of American Growth: The U.S. Standard of Living since the Civil War. Princeton: Princeton University Press.

Gordon, R 2014 (February). “The Demise of U.S. Economic Crowth: Restatement, Rebuttal, and Reflections.” NBER Working Paper No. 19895.

Gordon, R. 12012 (August). "Is U. S. Economic Growth Over? Faltering Innovation Confronts the Six Headwinds." NBER Working Paper 18315.

Gupta, H, S Kumar, S Kumar Roy, and R. S Gaud. 2010. “Patent Protection Strategies." Journal of Pharmacy and Bioallied Sciences 2 (1): 2-7.

Hayek, F1961. "The Non-Sequitur of the 'Dependence Effect'." Southern Economic Journal 27 : 346-348.

Heertje, A 1987. "Creative Destruction." In The New Palgrave: A Dictionary of Economics, edited by ] Eatwell, M Milgate, and P Newman, 1st ed. Palgrave Macmillan.

Heidhues, P, B Kőszegi, and T Murooka. 2016. “Exploitative Innovation.” American Economic Journal: Microeconomics 8 (1): 1-25. Hodgson, G. M 2002. "Darvinism in Economics: From Analogy to Ontology." Journal of Evolutionary Economics 12 : 259-281. Komlos, ] 2014. What Every Economics Student Needs to Know and Doesn't Cet in the Usual Principles Text. New York: Routledge.

Komlos, J Growth of Income and Welfare in the U.S., 1979-2011. NBER working paper, no. 22211 2016a, http://www.nber.org/papers/w22211. Komlos, ] (2016b).CesIfo working paper no. 5967 Another Road to Serfdom. 
Krugman, P 2012. End This Depression Now!. New York: W.W. Norton \& Co.

Krugman, P Secular Stagnation, Coalmines, Bubbles, and Larry Summers 2013. November162013. Accessed June112013.http://krugman.blogs.nytimes.com/2013/11/16/secular-stagnation-coalmines-bubbles-and-larry-summers/?.php=true\&_type=blogs\&_r=0.

Krugman, P Creative Destruction Yada Yada. The New York Times 2014. Accessed June 22 2014. June 16http://krugman.blogs.nytimes.com/2014/06/16/creative-destruction-yada-yada/.

Lepore, ] The Disruption Machine. What the Gospel of Innovation Gets Wrong. The New Yorker 2014. Accessed June $212014 .$. June 23http://www.newyorker.com/reporting/2014/06/23/140623fa_fact_lepore.

Leichtmann Research Group. Press Release: 83 \% ofU.S. households subscribe to a pay-tv service 2016. Accessed January302016. http://www.leichtmanresearch.com/press/090315release.html.

Mokyr, ] 2014. "Riding the Technology Dragon." Milken Institute Review 2 : 87-94.

Mokyr, J, C Vickers, and N. L Ziebarth. 2015. "The History of Technological Anxiety and the Future of Economic Growth: Is This Time Different." Journal of Economic Perspectives 29 (3): 31-50.

Moulton, B. R, T. J LaFleur, and K. E Moses. Research on Improved Quality Adjustment in the CPI: The Case of Televisions. Bureau of Labor Statistics 1998. Accessed January302016.. http://citeseerx.ist.psu.edu/viewdoc/download?doi=10.1.1.506.3183\&rep=rep1\&type=pdf.

Nordhaus, W, and J Tobin. 1973. "Is Growth Obsolete?." In The Measurement of Economic and Social Performance, edited by M Moss, 509-564. Cambridge, MA: NBER.

Offer, A 2006. The Challenge of Affluence: Self-Control and Well-Being in the United States and Britain since 1950. Oxford: Oxford University Press.

Olson, M 1984. The Rise and Decline of Nations: Economic Growth, Stagflation, and Social Rigidities. New Haven: Yale University Press.

Pasinetti, L 1993. Structural Economic Dynamics: A Theory of the Economic Consequences of Human Learning. Cambridge: Cambridge University Press.

Pearlstein, S Review: "The Second Machine Age," by Erik Brynjolfsson and Anderew McAfee. The Washington Post 2014. January17.

Piketty, T 2013. Capital in the Twenty-First Century. Cambridge, MA: Harvard University Press.

Schubert, C 2012. "Is Novelty Always a Good Thing? Towards an Evolutionary Welfare Economics." Journal of Evolutionary Economics 22 : 585-619.

Schubert, C 2013. “How to Evaluate Creative Destruction: Reconstructing Schumpeter's Approach." Cambridge Journal of Economics 37 (2): 227-250.

Schubert, C 2015. "What Do We Mean When We Say That Innovation and Entrepreneurship (Policy) Increase 'Welfare' ?" Journal of Economic Issues 49 (1): 1-21.

Schumpeter, ] 1942. Capitalism, Socialism and Democracy. New York: Harper.

Statistic Brain. 2014. accessed May 11. http://www.statisticbrain.com/fashion-industry-statistics/.

Stiglitz, ]. E 2012. The Price of Inequality: How Today's Divided Society Endangers Our Future. New York: W.W. Norton.

Stiglitz, J. E, A Sen, and ].-P Fitoussi. 2010. Mis-Measuring our Lives. Why the CDP Doesn't Add up. New York: New Books.

Stevenson, B, and ] Wolfers. 2013. "Subjective Well-Being and Income: Is There Any Evidence of Satiation?" American Economic Review: Papers \&Proceedings 103 (3): 598-604.

Summers, L Transcript of Larry Summers speech at the IMF Economic Forum, Nov. 8, 2013 2013. Accessed June112013.. https://m. facebook.com/notes/randy-fellmy/transcript-of-larry-summers-speech-at-the-imf-economic-forum-nov-8-2013/585630634864563.

Summers, L 2014a. “U.S. Economic Prospects: Secular Stagnation, Hysteresis, and the Zero Lower Bound.” Business Economics 49 (2): 65-73.

Summers, L 2014b. “Low Equilibrium Real Rates, Financial Crisis, and Secular Stagnation." In Across the Great Divide: New Perspectives on the Financial Crisis, edited by M. N Baily, and J.B., Taylor, 37-50. Hoover Institution, Stanford University number 8 ,

Tanner, E 1996. Why Things Bite Back: Technology and the Revenge of Unintended Consequences. New York: Knopf.

Teather, D Kodak Pulls Shutter down on Its Past. The Guardian 2014. Accessed June 4. January 22http://www.theguardian.com/technology/2004/jan/23/newmedia.gadgets.

Veblen, T 1899. The Theory of the Leisure Class. New York: Macmillan.

Vivarelli, M 2014. "Innovation, Employment and Skills in Advanced and Developing Countries: A Survey of Economic Literature." Journal of Economic Issues 48 (1): 123-154.

Vijg, ] 2011. The American Technological Challenge: Stagnation and Decline in the $21^{\text {st }}$ Century. New York: Algora Publishing.

Witt, U 1996. "Innovations, Externalities and the Problem of Economic Progress." Public Choice 89: 113-130.

Wolf., Martin 2016. 2016. "An end to facile optimism about the future," Financial Times, July 12. 